\title{
Opposition Buginese Society in Novel Silariang Cinta Yang (Tak) Direstui: An Intertextuality Study
}

\author{
Saharul Hariyono* \\ Indonesian Language and Literature Department \\ Universitas Negeri Yogyakarta \\ Yogyakarta, Indonesia \\ Saharulhariyono.2018@student.uny.ac.id
}

\author{
Nurhadi \\ Faculty of Language and Arts \\ Universitas Negeri Yogyakarta \\ Yogyakarta, Indonesia \\ nurhadi@uny.ac.id
}

\begin{abstract}
The author does not make texts from their original thoughts, but rather compiles from preexisting texts, so, the text is "a permutation" of intertextuality in the space of a given text from other text, intersect, and neutralize one another. Kristeva asserted that studying text (literature) as intertextuality like put it into social and historical text. This intertextuality is an ideologeme of a cross from the literature arrangement that will refer to the other text space. This paper discusses the novel Silariang Cinta Yang (Tak) Direstui with the opposition concept by Julia Kristeva. The opposition is always exclusive giving the illusion of an open structure, impossible to finish, never complementary and reconcile. Also, this paper is as an attempt to apply Julia Kristeva's theory of intertextuality which has not been sufficiently available in research studies. Research shows that opposition in the novel seen in socio-cultural aspects as the domain is occurred in the elopement (silariang), pride/shame (siri'), and social class. The domain opposition attitude and behavior between the young generation and the old generation.
\end{abstract}

Keywords- intertextuality, ideologeme, opposition, Buginese society, Novel Silariang Cinta Yang (Tak) Direstui

\section{INTRODUCTION}

Authors does not make texts out of their original thoughts, but instead arrange them from pre-existing texts, so the text is "a permutation" in the given text space where some of the spoken texts are taken from other texts, intersect and neutralize each other. In other words, no literature text emerges from the void, this matter is later known as the intertextuality concept. But, it needs to be emphasized in intertextuality discussion, that is not to see the similarities and differences of two or more different works, and hypogram by assuming the preceding text as a matrix, intertextuality looked like a text which has social and historical perspective (Nasri, 2017; Septiyani \& Sayuti, 2019).

This concept has been emphasized by Kristeva herself as the founder of this theory in the book Desire in Language: A Semiotic Approach to Literature and Art, confirmed that the text (in this literature) such as intertextuality inputs into social and historical texts (Kristeva, 1980). The intertextuality concept of Kristeva was emphasized by Nasri in her journal Oposisi Teks Anak dan Kemenakan Karya Marah Rusli: Kajian Intertekstual Julia Kristeva, some studies ever traced did not apply the concept intertextuality as it should be. Kristeva's book is clearly stated that intertextuality does not talk about the influence of one author over another or the influence of reading literary works (Nasri, 2017). Meanwhile, another study explained intertextuality is always inspired by social and historical situations (Nafisah, 2019). Julia Kristeva's contribution to the idea of intertextuality is essential. Kristeva did not only create the word intertextuality but substantially emphasized the importance of potential dynamics that exist in the text (Raj, 2015).

The intertextuality initiated by Kristeva is ideologeme quest in literary works. Ideologeme described that the text has no unity of meaning in itself, but it is always connected to social and historical process, the meaning (literary works) of the same time being in and at once outside the text (Allen, 2000; Al-Ahnomi, 2019). Ideologeme is the intertextual core that can be seen through the three processes from the use of opposition, transposition, and transformation (Kristeva, 1980).

As far as observed, the intertext's alignment can be seen in the novel Silariang Cinta Yang (Tak) Direstui (2017) by Oka Aurora. This novel is strong with social and historical Buginese society. The example used the clitic particles that are common to use by Buginese society to strengthen the power of narrative character novel such as: $-t a-k i,-m i,-j i,-k o,-k a,-p i$,toh. E.g, "Siapa nama-ta? Seru Yusuf dari kejauhan, who is your name? Yusuf questions from afar" (Aurora, 2017). Particle $-t a$ is a clitic ownership to you. The form of -ta often uses by Buginese speakers in Indonesian language in the environment and situations that are half or unofficial (Mokhtar, 2012).

Focusing on this study, the author will only talk about the concept of opposition, one of Kristeva's intertextuality meanings. Novel Silariang Cinta Yang (Tak) Direstui showed the opposition between comprehension of the young generation (represented by the characters of Yusuf and Zulaikha) and the old generation (represented by the characters of Puang Rabiah, Puang Abdullah, Puang Ridwan, and Dirham). This opposition covers the realm of sociocultural in viewing elopement (silariang), pride/shame (siri'), and social class. Also, this paper is as an attempt to apply the intertextuality theory by Julia Kristeva which has not yet been adequate supplementary in scientific research studies.

Concept of intertextuality by Julia Kristeva's was started from the thought of Mikhail Mikhailovich Bakhtin on the dialogue through Kristeva's essays in the late 60s like "The Bounded Text" and "Word, Dialogue, Novel" (Cruz, 2019; 
Lylo, 2017; Allen, 2000). Until now, Bakhtin's works is very influential in the field of theory and literature criticism, linguistics, and other disciplines. Intertextuality is the text constructed from the absorption of other text. Kristeva developed this concept from Mikhail Bakhtin's thought. Yet, what appears as a lack of rigor is, in fact, an insight that first introduced into literary theory by Bakhtin: any text is constructed as a mosaic of quotations; any text is the absorption and transformation of another. The notion of intertextuality replaces intersubjectivity (Kristeva, 1980). The term of intersubjectivity is a replacement for the conventional term "self." He considers intersubjectivity as a dynamic process that never reaches completion (Kabthiyal \& Dangwal, 2016). This can be seen that the idea of Bakhtin on intersubjectivity (concept dialogism) has been reorganized within the scope of Kristeva's attention on intertextuality.

Bakhtin's work is cantered on human as subject of the language in certain social situations, while Kristeva avoids human subjects. Kristeva supported words in text terms and textuality. However, Bakhtin and Kristeva have in common idea that the text cannot be separated from social or cultural text wider than the text that was built from the source (Allen, 2000). Study intertextuality became one of the attractions in the study of literary criticism by responding the contemporary understanding of the treatment from the text (Alawi, 2010).

Kristeva introduced Bakhtinian thoughts and then formulates the intertextuality word in French intertextualité. However, this theory has been widely misinterpreted, this has no relationship and influence by one author with another or with a source of literary work one with the other. In my book titled La Révolution du Langage Poétique, that intertextual as a transposition of one or more signs to another sign is accompanied by a new articulation (pronunciation) that is denotative (Kristeva, 1980). Intertextuality here, related to the emergence of text from "social text" but also appeared in society and history. Kristeva referred to an ideologeme that he borrowed from the concept of Mikhail Bakhtin (Allen, 2000; Kauppi, 2010).

Ideologeme as the text is the focus in the realm of rationality in understanding transformation of speech (the text cannot be reduced) so the text becomes totality in social and historical texts (Kristeva, 1980). Ideologeme form can be seen through three processes of meaning: First, the opposition is always exclusive by giving the illusion that is impossible to finish, never complement each other, and cannot be reconciled. Second, transposition is the process of the move from one sign system to another marking system. Third, transformation is the change of the form from one text to another (Kristeva, 1980).

\section{RESEARCH METHODS}

This research is a qualitative descriptive study (Moleong, 2017). The data in this study consists of primary and secondary data. The primary data is the novel Silariang Cinta Yang (Tak) Direstui by Oka Aurora published by Coconut Books in 2017. Secondary data is obtained from written reference sources such as books, journals, research reports, and other references related to this study. Data collection techniques used are the methods of reading and recording (read-record).

Data analysis methods follows the steps of intertextuality by Julia Kristeva, such as: first, suprasegmental analysis from related phrases, words, sentence, and paragraph contained in the framework of literary works, so it will reveal as a text bound or moving from within the text (interior text). Second, the intertextual analysis moved from the outside text, it illustrates the synchronous relationship in the novel text with the texts outside the novel (exterior text). Both of these analyses cannot be separated. Analysis is done to give the social and cultural codes found in the literary work (Kristeva, 1980; Vargova, 2007).

\section{RESULTS AND DISCUSSIONS}

Phenomenon caused by perspective that is occurred intergeneration is global tendency, and also all groups are facing this phenomenon. Generally, inter-generation phenomenon occurs among the youth and the old. They demand different perspective. This case causes cultural shock. The old groups are the generation who inherit and maintain traditional values, meanwhile, young generation with their rationality question the illogical traditional culture. This difference makes them oppose each other. This different perspective is pervaded in the Silariang Cinta Yang (Tak) Direstui Novel by Oka Aurora, who describes opposition phenomenon between the two generations. Such as the following discussion.

\section{Elopement (Silariang)}

Marriage is coveted matter for every human beings to fulfill it. However, in social reality, many people are not able to fulfill their desire, for instance, they do not have parent's blessing, even constrained with the marriage dowry. Then, it emerges the idea of elopement. This eloping practice can be seen in the narration of Silariang Cinta Yang (Tak) Direstui that discuss on marriage practice especially elopement in Buggenese society in South Sulawesi. Silariang is basically occurred because of love which bonds strongly between spouse, but the love gets obstacle or hindrance from the parents, even because of the dowry that is too expensive (panai). Israpil (2015) explaines that silariang is a marriage that violates custom rules, and the person who undertakes silariang, in this case, his action is really hazard and full of risk.

The narration of the novel also describes the same thing that Silariang is very dangerous for the culprit. Such as the character of Yusuf and Zulaikha in this novel who choose shortcut action by doing elopement. Silariang can be said as the last solution chosen to fight for their love. However, their action is full of risk and certainly triggers long-term conflict.

Zulaikha menatapnya dengan bingung. "Kita pergi jauh dari sini," lanjut Yusuf. Zulaikha membelalak, "Ke mana?" "Ke mana aja. Yang penting, kita berdua. Kita sama saya. Kita ji saja berdua." Zulaikha semakin terperangah. "Silariang?" Kaki Zulaikha langsung lemas. Ia terduduk begitu saja di tepi jalan sepi itu. "Taruhannya nyawa, Suf." (Aurora, 2017: 40). 
Zulaikha stares with confused. "We are leaving far away," said Yusuf. Zulaikha is shocked, "to where?" "Anywhere is fine. Importantly, we both. You and me. We ji both of us." Zulaikha is getting more shocked "Silariang?" Zulaikha's feet instantly becomes limp. She just sits on the side of the road. "The stakes are our lives. Suf." (Aurora, 2017: 40).

The description above describes that Yusuf asks Zulaikha for eloping. However, their action has deviated from Buginese Custom. This case causes opposition with Zulaikha's family that is represented by Puang Rabiah, and Dirham. They consider that Yusuf and Zulaikha's action will break the brotherhood ties among fellow society and also create shock even conflict. Puang Rabiah wants Zulaikha to marry with someone ideal who has the same level. Zulaikha is a woman who was born from a noble mother; therefore, she must be married to the same class.

Rabiah menjawab lembut, "Masih banyak ji pemuda bangsawan yang lebih layak untukmu.” (Aurora, 2017: 44).

Rabiah reply gently, "There are still many young noblemen who is worthy for your ji." (Aurora, 2017: 44).

"Kalau sama dia, kau tidak akan mendapat restu dari saya." (Aurora, 2017: 20).

"If you go through with him, you will not get my blessing." (Aurora, 2017: 20).

According to Buginese society, an Ideal marriage is marriage that is equal in social strata (siratang). Kasiratangan is an equal and the same strata relation that will not cause uproar in the society (Israpil, 2015). This is what instilled by Puang Rabiah to Zulaikha in order to avoid conflicts opposed by the society. The youth consider silariang as a courage symbol because it can breach kinship value that is so strong in Buginese society. On the contrary, the oldies view on silariang, it only will cause long lasting conflict between families and the surrounding society.

\section{Shame/Pride (Siri')}

The second opposition brought in this narrative fiction is the concept of siri'. Siri' is understood as the ability to defend honor and dignity to the people who want to insult, disgrace family or relative. Besides, siri' is also identical with shame. Through the concept of Yusuf and Zulaikha as the youth, it is considered that siri' as a system to defend their pride. Meanwhile Puang Rabiah, Ridwan as the older considers that siri' as action to uphold the shame. Siri' is the most principal element in Buginese society, there is no other value that is most precious to be defended and maintained except siri' (Pelras, 1975; 1996) .

Expression of siri' that is conducted by Yusuf and Zulaikha as courage in the manifestation of protest to parents who did not approve their love relation, thus, this action is considered in responding the parent's stance. Due to this event, then it emerges tension within society, especially the woman's family who runs or runs away. Except, if the man has already been in a house or a yard of customary leader or at least he has thrown his head cover (cap) into the yard of the house, it means he is in the protection, then he cannot be disturbed anymore, so that, this action is regarded as common action by the Buginese society to uphold siri' (Suwondo, 1978). This case is manifested in Yusuf and Zulaikha's narration by visiting the house of religious figure (priest/customary member) as a sign that they are in protection.

Pak imam tak mengindahkan jawaban Yusuf. "Kita yakin mau lari seperti ini? Saya tidak menyalahkan cinta. Tapi orang silariang, jarang yang kuat bertahan. Yang direstui saja belum tentu bahagia, apalagi yang tidak." Si imam menatap Yusuf dalam-dalam, menguji tekadnya. Sesaat, Yusuf digoyang bimbang. Tapi lalu ia menjawab dengan nada ragu-ragu, "Yakin Pak Imam..." Pak Imam mengalihkan perhatiannya ke Zulaikha. Sadar kalau diperhatikan, Zulaikha memberanikan diri mengangkat wajahnya. "Tolong kami, Pak Imam," bisiknya (Aurora, 2017: 58-59).

Mr. priests ignores Yusuf's answer. "You certainly want to do elopement like this? I am not blaming on love, but silariang person, are rarely can survive. Even they who are blessed are not necessarily happy, especially those who are not". The priest stares Yusuf deeply, tests on his will. At moment, Yusuf is hesitating. But the he answers in doubt, "Certainly, Mr. Priest..." Mr. priest turns his attention to Zulaikha. She awares of being attention, Zulaikha lifts her face. "Help us, Mr. Priest," she whispers (Aurora, 2017: 58-59).

Siri' for Yusuf and Zulaikha as the form of protection, pride as well as self-actualization for maintaining their love bond. The deep love from the spouse makes them become opposition toward the parents. Meanwhile, Puang Rabiah and Ridwan regards siri' as manifestation to uphold the feeling of shame caused by Yusuf, because of eloping (silariang) Zulaikha, their daughter. This case is considered as challenge and insult toward family's honor, regarding Zulaikha's family is noble family. However, actually Zulaikha leaves with her lover (Yusuf) is based on their will, but Yusuf still takes on the blame. Zulaikha's family has the obligation to end the man's life in the tip of dagger in order to restore back the shame. Below shows Zulaikha's uncle, Ridwan, to uphold family's siri'.

"Puang," bisik Ridwan, "saya terima badik ini sebagai janji untuk menjunjung tinggi siri' Puang dan keluarga. Semoga Allah Ta'ala memberi saya kekuatan untuk menjaganya." (Aurora, 2017: 55).

"Puang," Ridwan whispers, "I receive this dagger as a promise to uphold Puang's siri' and family. I hope Allah Ta'ala gives me the strength to keep it." (Aurora, 2017: 55).

"Tabe, kita tahu bahwa saya telah diamanahkan oleh etta-nya Zulaikha untuk menjaga dan melindungi siri' keluarga. Maka perkenankan saya menghapus malu yang mencoreng muka kita." (Aurora, 2017: 61)

"Tabe, we know that I have been mandated by Zulaikha's etta to keep and protect family's siri'. Then, allow me to eliminate the shame that insult our face." (Aurora, 2017: 61). 
Based on the above description, for Buginese society, siri' is their soul. Therefore, to uphold and restore the shame caused by the other, then Buginese society has willing to sacrifice anything include their most precious soul. As had been done by Ridwan in remembering message and trustworthy of Puang Abdullah (etta/Zulaikha's father) must maintain family's siri' (shame/pride).

\section{Social Class}

South Sulawesi inherits royal tradition that is quite strong among others: Bone, Gowa, and Luwu. The three kingdoms are grand kingdoms and very influential in their era (Haris, 2018). As the effect, some influence of the kingdom, the descendant of the king attached noble title as a mark to differentiate noble and common, Buginese applies principle of "white blood" human as descendant of the dewata (God and King), and also they who have "red blood" is categorized as common people (Meiyani, 2010). One of them is using Puang title in the King Bone descendant, which means ruler, leader, and protector.

Silariang Cinta Yang (Tak) Direstui text is a novel which is very full of Buginese setting, this can be seen from the use of the names of characters imaginary who has nobility title as represented by Zulaikha's family, such as Puang Rabiah, Puang Ridwan that is described as descendant of Gowa King. Identity possessed by Zulaikha's family makes their gesture is limited by rules, and every word becomes role model. This situation is inversely proportional, Yusuf is merely from ordinary people, his parents are actually businessman. However, in Buginese family tree, the work held by Yusuf's parents means nothing if it compares to the nobles. Opposition discourse emerges when Yusuf wants to propose Zulaikha which does not end beautifully or according to plan. This is seen in the narration that depicts character Jay (Yusuf's uncle) and his wife is given the trustworthy to propose Puang Rabiah's daughter.

Jay menyeruput air teh yang dihidangkan bagi ia dan istirinya. Dari tepian cangkir teh, ia mencuri lirik ke Ridwan dan Zulfi yang duduk di hadapannya dengan tegang. "Pahit," ia berbisik ke istrinya, mengomentari rasa teh itu. Jay langsung kebitkebit. Teh pahit yang dihidangkan bangsawan Bugis bisa berarti banyak hal, namun semuanya tak mengenakkan. Dengan rasa teh ini, Jay berfirasat. Bosarak-bosarak Jay yakini penuh berisi kue rumahan tak akan dibukakan bagi mereka; tamu-tamu yang tak diharapkan. Sepertinya, maksud kedatangan mereka akan telak-telak ditolak (Aurora, 2017: 2526).

Jay sips the tea that is served for him and his wife. From the tea cup edges, he squints to Ridwan and Zulfi who sit calmly in front of him. "Bitter", he whispers to his wife, comments on the tea flavor. Jay is instantly agitated. Bitter tea that is served in Buginese noble could be meant a lot of things. But all of them are unpleasant. With this tea flavor, Jay had a feeling, those bosaraks he believes are full of cookies will not be served for them, unexpected guests. It seems, their intention will be rejected bluntly (Aurora, 2017: 25-26).

On this context, Zulaikha's family is strongly refused the proposal because Yusuf is only a person from ordinary circles.
The issue is getting outburst with the one-sided decision of Yusuf's father (Dirham) that is also turn down the proposal, because he realizes that his family is not worthy married with King's descendant and it will make siri' (pride), also dropped the dignity of Yusuf's family.

\begin{abstract}
"Tapi ini harga diri," lanjut Dirham. "Darah kita bukan darah bangsawan. Кати mau Bapak keluar uang, beli darah, supaya bisa ko menikah sama dia? Kita injak-injak harga diri-ta? Untuk apa? Cinta?" (Aurora, 2017: 32).
\end{abstract}

"But this is pride," Dirham continues. "Our blood is not noble blood. You want me to spend money, buy this noble blood, in order you marry with her? You want to disgrace ourselves? What for? Love?" (Aurora, 2017: 32).

Based on the above description, it seems that Dirham is also portrayed as opposed and strictly forbid Yusuf and Zulaikha's relationship. However, this treatment is not shrunk Yusuf and Zulaikha to defend their love, instead, it makes itself resistant that caste differences do not have to make things wobble. As for this matter, they want by silariang (eloping), willing to live poor and suffer, leave all the luxury. It appears, Yusuf and Zulaikha are resistance themselves to fight the social class that has already constrained in the Buginese society that has ingrained in their life.

\section{CONCLUSIONS}

Based on the data analysis that opposition text Silariang Cinta Yang (Tak) Direstui occurs in the different perspective about elopement (silariang), shame/pride (siri'), and social class. This different perspective is described clearly among the youth (Yusuf and Zulaikha) and the old (Puang Rabiah, Puang Ridwan, and Dirham). Therefore, the both groups could not be united in their thoughts and perspectives, at once, it describes social and historical context happened in Buginese society. This is according to Kristeva's intertext concept that literary text is an intersection that will refer to outside space context, which are: social and historical condition.

\section{ACKNOWLEDGMENT}

The researcher expresses his gratitude to Mr. Nurhadi, lecturer in Faculty of Language and Art State University of Yogyakarta who has helped in validating and verifying the data findings.

\section{REFERENCES}

Al-Ahnomi, M. M. (2019). Analyzing intertextual relations between "Othello" and "Season of Migration to the North." Journal of Literature, Languages and Linguistics, 60(1), 1-7. https://doi.org/10.7176/j11//6001

Alawi, N. (2010). Intertextuality and literary translation between Arabic and English. An-Najah Univ. J. of Res. (Humanities), 24(8), 2438-2456. Retrieved from https://journals.najah.edu/article/239/

Allen, G. (2000). Intertextuality: The new critical idiom ('st ed.). New York: Routledge.

Aurora, O. (2017). Silariang cinta yang (tak) direstui. Depok: Coconut Books.

Cruz, E. C. (2019). Memories and mindscapes: An intertextual study of Haruki Murakami's Norwegian Wood. IAFOR Journal of Arts \& Humanities, 6(1), 75-86. https://doi.org/10.22492/ijah.6.1.07 
Haris, R. (2018). Dinamika kelompok sosial budaya di kota Makassar: Memudarnya stratifikasi sosial berbasis keturunan. Jurnal Masyarakat Dan Budaya, 19(2), 189-202. https://doi.org/10.14203/jmb.v19i2.399

Israpil. (2015). Silariang dalam perspektif budaya siri’ pada suku Makassar. Jurnal Pusaka, 2(2), 53-67. Retrieved from http://ejournal.alqolam.ac.id/index.php/jurnal_pusaka/article/view/23

Kabthiyal, N., \& Dangwal, S. (2016). On Kristeva concept of intertextuality. International Journal of English Language, Literature and Translation Studies, 3(1), 298-303. Retrieved from http://www.ijelr.in/3.1.16/298303 NIYATI KABTHIYAL.pdf

Kauppi, N. (2010). Radicalism in French culture: A Sociology of French Theory in the 1960s. London: Routledge.

Kristeva, J. (1980). Desire in language a semiotic approach to literature and $\operatorname{art}\left({ }^{1}\right.$ st ed.). New York: Columbia University Press.

Lylo, T. (2017). Ideologeme as a representative of the basic concepts of ideology in the media discourse. Social Communication, 1, 14-20. https://doi.org/10.1515/sc-2017-0002

Meiyani, E. (2010). Sistem kekerabatan orang Bugis di Sulawesi Selatan (Suatu analisis Antropologi - Sosial). Jurnal Al-Qalam, 16(1), 181190. https://doi.org/10.31969/alq.v16i2.484

Mokhtar, M. (2012). Interferensi morfologis penutur bahasa Bugis dalam berbahasa Indonesia. Humaniora, XII(2), 219-224. https://doi.org/10.22146/jh.v12i2.693

Moleong, L. J. (2017). Metodologi penelitian kualitatif. Bandung: PT. Remaja Rosdakarya.

Nafisah. (2019). Ideologeme novel Raden Mandasia Si Pencuri Daging Sapi karya Yusi Avianto Pareanom: Kajian intertekstualitas Julia Kristeva (Thesis, Universitas Gadjah Mada Yogyakarta). Retrieved from https://www.academia.edu/40288808/Ideologeme_Novel_Raden_Man dasia_Si_Pencuri_Daging_Sapi_Karya_Yusi_Avianto_Pareanom_Kaji an_Intertekstual_Julia_Kristeva

Nasri, D. (2017). Oposisi teks Anak Dan Kemenakan karya Marah Rusli: Kajian intertekstual Julia Kristeva. Kandai, 13(2), 205-222. https://doi.org/10.26499/jk.v13i2.92

Pelras, C. (1975). Introduction à la littérature Bugis. Archipel, 10(1), 239-267. https://doi.org/10.3406/arch.1975.1252

Pelras, C. (1996). The Bugis ( ${ }^{1}$ st ed.). Cambridge: Blackwell Publishers Ltd.

Raj, P. P. E. (2015). Text/Texts: Interrogating Julia Kristeva's concept of intertextuality. Ars Artium: An International Peer Reviewed-CumRefereed Research Journal of Humanities and Social Sciences, 3(1), 77-80. $\quad$ Retrieved from https://www.academia.edu/download/55502753/Ars_Artium_2015.pdf \#page $=83$

Septiyani, V. I., \& Sayuti, S. A. (2019). Oposisi dalam novel Rahuvana Tattwa karya Agus Sunyoto: Analisis intertekstual Julia Kristeva. Lensa: Kajian Kebahasaan, Kesusastraan, Dan Budaya, 9(2), 174186. https://doi.org/10.26714/lensa.9.2.2019.174-186

Suwondo, B. (1978). Adat dan upacara perkawinan daerah Sulawesi Selatan. Jakarta: Departemen Pendidikan dan Kebudayaan.

Vargova, M. (2007). Dialogue, pluralism, and change: The intertextual constitution of Bakhtin, Kristeva, and Derrida. Res Publica, 13(4), 415-440. https://doi.org/10.1007/s11158-007-9042-y 